\title{
Influence of Parental Involvement, Parental Support and Family Education on Pupils' Adjustment in Lower Primary Schools in Osun State
}

\author{
Dr. B. A. Adeyemi ${ }^{1}$, Dr. (Mrs) V. O. Adediran' ${ }^{2}$, O. S. Adewole ${ }^{3}$ \\ ${ }^{1,2}$ Institute of Education, Obafemi Awolowo University, Ile-Ife, Nigeria \\ ${ }^{3}$ School of Education, Osun State College of Education, Ila-Orangun, Nigeria
}

*Corresponding Author: Dr. B. A. Adeyemi, Institute of Education, Obafemi Awolowo University, IleIfe, Nigeria

\begin{abstract}
The study examined the level of parental involvement in school adjustment in lower primary schools in Osun State. It also investigated the effect of parental socio-economic status on parental involvement in pupils' school adjustment. It further investigated the relationships among home variables, school variables and parental involvement in school adjustment. The study employed correlational research design. The population consisted of parents of lower primary school pupils in Osun State. The sample size consisted of 300 parents. An instrument titled 'Parental Involvement, Parental Support and Family Education on Pupils' Adjustment Questionnaire'; (PIPSFEPAQ) was developed and validated before used. Three research questions emanated from the study. Data collected were analysed using simple percentage and multiple regression analysis. The results among others revealed that $36.6 \%$ of the respondent indicated that there was high level of parental involvement in school adjustment. It further showed home variable $(r=$ $0.824, p<0.05)$ and school variable $(r=0.815, p<0.05)$ are significantly correlated to parental involvement. The study concluded that parents have a lot to do in creating a conducive home environment that would promote pupils' adjustment in schools.
\end{abstract}

Keywords: Pupils’ adjustment, School, Parental Involvement.

\section{INTRODUCTION}

The transition from home to school is a major change in children's lives, being the first compulsory and universal point of contact between the child and broader social institutions. This can be a challenging period for children, as they adjust to a generally much larger institution than they have previously encountered-with its own culture, rules and expectations, along with new people (both teachers and school mates), and the new physical environments of classrooms and playgrounds.

There is clear evidence that children vary in their "readiness" for this transition, with marked differences visible in children's cognitive and social/emotional skills when they enter school. The importance of making a good transition into school is indicated by evidence that school readiness is predictive of later outcomes: children who are less "ready" are less likely to excel academically, are more likely to have behavioural and emotional problems, be retained in a grade and drop out of school (Duncan 2007). Such children are also more likely to become teenage parents, engage in criminal activities and have poorer employment records (Schweinhart, 2003).

While early conceptualizations of school readiness focused on children's readiness for school, there has been a recent expansion of these ideas to include the school's, families' and communities readiness for this transition - This re-conceptualization recognises the interaction between children's inherent characteristics and the environmental and cultural context, of children's learning experiences in determining their readiness for school. It has been significantly influenced by Bronlènhrenner's (1979) ecological systems theory which contextualizes child development within the relationships that form the child's environment. This model incorporates factors that represent layers to influence on children's development related to the child, the family, the child's early childhood care, and the broader neighborhood, school policy and cultural context. According to this model, child development occurs in the context of these overlapping, interconnected influences and relationships. 
Research has identified various child characteristics that play a role in school readiness. One such factor is children's early cognitive ability, which has consistently been found to influence cognitive and language abilities when starting school (Dearing, McCartney \& Taylor 2001; Duncan\& Brooks' Gunn, 1994). Early cognitive ability has been found to be a relatively strong predictor of school readiness, having a large impact than other child characteristics (e.g. gender, birth weight) and family characteristics (e.g. maternal education, family structure, ethnicity, income) (Dearing et al., 2001).

Children's temperament is another factor affecting school readiness having been found to explain between $25 \%$ and $30 \%$ of variance in class room behaviour (Guerin \& Gottried, 1994). When considering various aspects of temperament, lower levels of activity and distractibility and higher levels of persistence have been found to be particularly important for academic achievement, while lower levels of reactivity and higher levels of adaptability and sociability have been found to the important for social/emotional adaptation to the school environment (Sanson, Ilemphill, \& Smart, 2002).

While both cognitive ability and temperament have a large genetic component, both can be modified through the child's interactions with the environment, such as the provision of stimulating, play experiences and sensitive care giving.

Given this evidence that a "good start" to schooling is so influential for later wellbeing. School readiness encompasses not only a child's readiness for school, but also their schools, families and community's readiness for this transition.

Parenting style which refers to the ways in which parents go about raising their children has been found to strongly impact on child outcomes. Supportive authoritative parenting (characterized by firm control calm discussion, proactive teaching and warmth) has been found to be related to stronger cognitive skills and fewer behaviour problems (Linver, Brooks-Gunn \& Kohen, 2002:

Pettit, Bates \& Dodge, (1997) assert that conversely, hostile and authoritarian parenting (characterised by a high value being placed at obedience, little verbal give and take, few explanations of rules, a punitive orientation, and low warmth) has been found to be related to poorer cognition and more behaviour problems (Hill, 2001; Linver et al, 2002; Pettit et al, 1997) Hostile, non-affectionate and coercive parenting (characterised by yelling, insults, swearing, meanness and physical punishment) has been found to be related to higher levels of behaviour problems, such as aggression (McFadyenKetchum, Bates, Dodge \& Pettit, 1996). The importance of parenting in early childhood is evident from the finding that less effective parenting at 6 months of age was related to academic, social emotional and behavioural problems in the first and second grade (Egeland, Pianta, \& Obrien, 1993).

\subsection{Parental Support Variables}

\subsubsection{Provision of Breakfast}

Breakfast plays a very important part in the teaching and learning process in the morning. It makes the pupils alert in class and helps them concentrate on the lessons being taught. However, when pupils are hungry they would not be active in class and would not concentrate on the lessons. The lack of breakfast meant that they were not too active class and could not concentrate and this affected their academic performance and adjustment. They needed stable frame of mind to enable them concentrate on learning and improve their output.

\subsubsection{Provision of Basic Needs}

The lack of basic school needs could not provide a stable mind and conducive environment for the pupils to study. They would not be able to concentrate on the classroom learning process and perform creditably. Lack of exercise books and writing materials result in the situation where the pupils could not do any assignments in the class but became onlookers or bystanders.

\subsubsection{Interaction with Children's Teachers}

Interactions with teachers enables the parents to know what problems their children are encountering in school and what could be done to deal with the problems. It would also put the pupils on the alert and then study on school because they would know that their parents would come and inquire about their performance in school. 


\subsubsection{Impact of Parental Involvement on Pupils' Adjustment}

Parental involvement takes many forms including good parenting in the home, provision of a secure and stable environment, intellectual stimulation, parent-child discussion, good models of constructive social and educational values and high aspirations relating to personal fulfillment and good citizenship, contact with schools to share information, participation in school events, participation in the work of the school, and participation in school governance. Parental involvement is strongly positively influenced by the child's level of attainment: the higher the level of attainment, the more parents get involved.

The extent of parental involvement diminishes as the child gets older and is strongly influenced at all ages by the child characteristically taking a very active mediating role. Differences between parents in their level of involvement are associated with social class, poverty, health, parental perception of their role and their levels of confidence in fulfilling it. Parenting has its influence indirectly through shaping the child's self-concept as a learner and through setting high aspiration. Parental involvement reveals a large no of approaches ranging from parent training programme through initiatives to enhance home school links and on to programmes of family and community education. According to Carlson (1991), parents are the primary influence in child's lives. Parent's involvement starts from birth and continues to adulthood. Parents must be seen no as external parties but as a full partner in the school community.

Empirical evidence suggested that parent's involvement in their children's schoolwork is positively related to academic success. In other words, parents who help in their children's homework and check their schoolwork with them tend to develop a good home-school linkage which is highly essential for children's success. Steinitz and Werby (1996) submitted that parents could help children establish good learning habits and promote active lifelong learning by helping Children to complete their homework. Such parental involvement seems to motivate children because children believe that they do better in school when their parents help them with their homework even though they express mixed feeling about how much they enjoy working with their parents.

\subsection{Influence of Socio-Economic Status on Pupils' Adjustment}

Achievement of learners in schools are based on the level of awareness of parents and their children, choice of educational institution and subsequent entry into such institution, It is also based on choice of course, the learning processes, ability to complete the school and the type of employment secured.

Similar studies Farrell (2003); Peter, Seeds, Goldstein and Coleman (2008); Deal and Peterson (2009); Baeck (2010) and Jafarov (2015); and Adewunmi (2015) have asserted that social stratification has influence on school adjustment in various ways such as: -

- Early Attendance at school: People of high class tend to send their children to school early, The children attend nursery schools as early as three years of age. People of low class send their children to school at six years age or later. Some could not even send their children to school at all. While children of high class complete primary education at 10 or Ii, those of low class do not complete until about 12 or 14 years.

- Provision of Education Facilities: - High-class people haves the financial means to provide books and other learning materials for their children. Also they are able to employ extra service of competent teachers for extra lessons. These make their children to be high.er achievers in schools inure than their counterparts.

- Encouragement in school Education: - Children of high class are encouraged to wake up early and prepare for school. Their parents show more concern over poor performance in schools. They teach their children or employ experts to teach them. They give more motivation to their children. Children from low class are hardly encourage to attend school, there is less concern about the children's poor performance and they are engaged in various domestic work which usually keep them late or completely away from school.

- Attendance at the Best schools: - Children of high class are sent to private schools and other school is with sufficient teaching and learning facilities. The schools charge high fees hich low-income 
earners may not be able to afford. Admission into such schools is usually through competitive examination which children from poor family may not be adequately prepared for. Also, the standard of living in the school is higher than the low- income group can afford. Children of high class are opportune to attend standard school, and thus secure admission into.

- Opportunity for good foundation in Education:- Being able to attend Standard School, children of high class people learn subjects like English Language, Mathematics, and basic science which provides them the foundation knowledge for learning other subjects. Teachers, standard textbooks and other learning facilities are available for the subjects. The children s basic knowledge serve as motivation for further studies and, as tools for higher achievement. However, the children of low class people according to Adewunmi (2015) attend low standard Public Primary School with inadequate infrastructure, inadequate teaching or instructional materials, incompetent and unqualified teachers and lack of school.

- Development of Interest in School Activities: - Children of high class attend schools where all round development of the child is taken into consideration. The children also take part in various school programmes that are meant for all round development. They have facilities for such activities at home (e.g. sports) and what they do in school is a continuation of the home activities. The opposite is the case for the children of the low class. Unlike their counterparts who are from high class, they (children from low class parents) embark or running series of errand debarring them of enjoyment like their classmates from the high class.

- Academic and job Aspirations: - The influence of parental socio-economic status is so powerful in pupils' occupational aspirations. The child lives with the parent and identities with the family climatic environment or socio-economic status which has direct bearing in his thought about his future aspirations. The family is also important for the occupational - socialization of the child. The effect of the family on child's occupational aspirations is worthy of note because the children pick up the social skills and the background to the jobs they do in later life.

\subsection{Purpose of the Study}

The specific purpose of this study are to:

- Assess the level of parental involvement in school adjustment;

- Determine the effect of parental economic status on pupils school adjustment; and

- Investigate the relationship among home variables, school variables and parental involvement in school adjustment.

\subsection{Research Questions}

The following research questions were asked for the purpose of achieving the objectives of this study:

- What is the level of parental involvement in school adjustment?

- What is the effect of parental socio-economic status on parental involvement in school adjustment?

- What are the relationship among home variables, school variables and parental involvement in school adjustment?

\section{Methodology}

The research design employed was survey which is ex-post facto research design. The population for the study consisted of all the parents of lower primary school pupils in Osun State. A sample of 300 parents was drawn from three local government areas. 10 lower primary schools were selected from each of the local government areas using simple random sampling technique. 10 pupils whose parents are salary earners were then selected from each of the schools through purposive sampling technique. One instrument was developed and used for data collection. The instrument is titled 'Parental Involvement, Parental Support and Family Education on Pupils' Adjustment Questionnaire' (PIPSFEPAQ). It was designed to assess the level of parental involvement in school adjustment, 
determine the effect of parental economic status on pupils' school adjustment and to investigate the relationship among home variables, school variables and parental involvement in school adjustment. The items on the questionnaire were scored on a five-point Likert scale that is 1 for Strongly Disagree, 2 for Disagree, 3 for Undecided, 4 for Agree and 5 for Strongly Agree. The items were responded to by the parents of the selected pupils. The instruments were validated by experts before use. The data collected were analysed using percentage and multiple regression analysis.

\section{RESUltS}

\subsection{Research Question 1: What is the level of parental involvement in school adjustment?}

To answer this research question, the respondents' responses on parental involvements (items $1,2,3,4,5,6,7,8,12,40,41,43,45,46$ and 47) in the students' adjustment are scored in such a way that $\mathrm{SD}$ is scored 1, D is scored $2 \mathrm{U}$ is scored $3 \mathrm{~A}$ is scored 4 and SA is scored 5. The resulting score is cumulated and used to build a measure of parental involvement in school adjustment. The mean score was found to be Approximately 53 with a standard deviation of approximately 11 . Scores of 31 or less (that is less than 2 standard deviation) were said to denote very low level of parental involvement while score of 32 to 42 (between 1 and 2 standard deviations) were said to mean low level of parental involvement. Scores of 43 to 53 are said to denote moderate involvement (scores between the mean and 1 standard deviation below the mean) while scores of 54 to 64 (one standard deviation above the mean) are said to be high level of involvement and scores above 64 (more than 2 standard deviation) are said to be very high. These categories are then given a descriptive analysis and the result is presented in table 1.

Table1. Level of Parental Involvement in school adjustment

\begin{tabular}{|l|l|l|}
\hline & \multicolumn{1}{|c|}{ Frequency } & \multicolumn{1}{|c|}{ Percent } \\
\hline Very low level of parental involvement & 13 & 4.3 \\
\hline Low level of parental involvement & 54 & 18.0 \\
\hline Moderate level of parental involvement & 80 & 26.7 \\
\hline High level of parental involvement & 109 & 36.3 \\
\hline Very high level of parental involvement & 44 & 14.7 \\
\hline Total & 300 & 100.0 \\
\hline
\end{tabular}

The table above shows the respondents views concerning the parental involvement in school adjustment, It can be seen from the table that most of the respondents $(36.3 \%)$ indicated that high level of parental involvement is necessary in school adjustment while $26.7 \%$ of the respondents were of the opinion that moderate level of parental involvement will be needed for school adjustment, in fact, $14.7 \%$ suggested that very high level is necessary. Only $18 \%$ indicated that low level of parental involvement is needed while $4.3 \%$ indicated very low level.

\subsection{Research Question 2: What is the effect of parental socio-economic status of parental involvement in pupils' school adjustment?}

Table2. Level of parental involvement

\begin{tabular}{|c|c|c|c|c|c|c|c|}
\hline & \multicolumn{5}{|c|}{ Level of parental involvement } & \multirow[b]{2}{*}{ Total } \\
\hline & & $\begin{array}{c}\text { Very low level of } \\
\text { parental } \\
\text { involvement }\end{array}$ & $\begin{array}{c}\text { low level of } \\
\text { parental } \\
\text { involvement }\end{array}$ & $\begin{array}{c}\text { Moderate level of } \\
\text { parental } \\
\text { involvement }\end{array}$ & $\begin{array}{c}\text { High level of } \\
\text { parental } \\
\text { involvement }\end{array}$ & $\begin{array}{c}\text { level of } \\
\text { parental } \\
\text { involvement }\end{array}$ & \\
\hline \multirow[t]{2}{*}{ Income } & $\begin{array}{l}\text { Below } \\
10000\end{array}$ & $4(1.4 \%)$ & $24(8.2 \%)$ & $21(7.2 \%)$ & $25(8.5 \%)$ & $2(0.7)$ & $76(25 \%)$ \\
\hline & $\begin{array}{l}10000- \\
50000\end{array}$ & $7(2.4 \%)$ & $28(9.6 \%)$ & $53(18.1 \%)$ & $50(17.1)$ & $31(10.3 \%)$ & $169(57.7 \%)$ \\
\hline \multicolumn{2}{|l|}{ Total } & $13(4.5 \%)$ & $53(18.1 \%)$ & $79(27 \%)$ & $104(27 \%)$ & $44(15 \%)$ & $293(100 \%)$ \\
\hline
\end{tabular}

In Table 2 above, the result reveals that less than $50 \%$ of the sampled parents earns below $\$ 10,000.00$ which signifies very low level of income while $0.7 \%$ earns above N50,000.00. Parents who earn very high income are $15 \%$ and these are 44 in number while those with high level of income spans at $29 \%$. The implication here is that $35.5 \%$ of the sampled parents earns proportionally highest level of income. 


\subsection{Research Question 3: What are the relationship among home variables, school variables and} parental involvement in school adjustment?

Table3. Level of parental socio-economic status

\begin{tabular}{|l|l|l|l|l|}
\hline & & $\begin{array}{l}\text { Parental Involvement } \\
\text { in school adjustment }\end{array}$ & HV & SCV \\
\hline Pearson Correlation & Parental Involvement in school adjustment & 1.000 & .824 & .815 \\
\hline & HV & .824 & 1.000 & .824 \\
\hline & SCV & .815 & .824 & 1.000 \\
\hline Sig. (1-tailed) & Parental Involvement in school adjustment &. & .000 & .000 \\
\hline & HV & .000 &. & .000 \\
\hline & SCV & .000 & .000 &. \\
\hline N & Parental Involvement in school adjustment & 300 & 300 & 300 \\
\hline & HV & 300 & 300 & 300 \\
\hline & SCV & 300 & 300 & 300 \\
\hline
\end{tabular}

Above $500002(0.7 \%) 1(0.3 \%) 5(1.7 \%)$

Table 3 shows the correlation of the first two variables with parental involvement in school adjustment in order to determine which of them goes into the steps first. From the table it can be seen that the two variables are significantly correlated to parental involvement in school adjustment. For Home variable, $r=0.824$ at $p<.05$ and for school variable, $r 0.815$ at $p<.05$. The table shows that the Home variables seem to be more highly correlated with parental involvement in school adjustment. Consequently, it goes first into the stepwise multiple regression procedure and the school variables follow later. The result is presented in table 4 below.

Table4. Model Summary

\begin{tabular}{|l|l|l|l|l|l|l|l|c|c|}
\hline Model & $\mathbf{R}$ & $\mathbf{R}$ & \multirow{2}{*}{$\begin{array}{c}\text { Adjusted R } \\
\text { Square }\end{array}$} & $\begin{array}{l}\text { Std .Error of } \\
\text { the Estimate }\end{array}$ & \multicolumn{4}{|c|}{ Change Statistics } \\
\cline { 5 - 9 } & & & \multicolumn{1}{|c|}{ R Square Change } & F Change & dfl & df2 & sig \\
\hline $\mathbf{1}$ & $.824(\mathrm{a})$ & .679 & .678 & 6.6112 & .679 & 629.826 & 1 & 298 & .000 \\
\hline 2 & $.858(\mathrm{~b})$ & .737 & .735 & 5.9969 & .058 & 65.171 & 1 & 297 & .000 \\
\hline
\end{tabular}

a. Predictors: (Constant), HV

b. Predictors: (Constant), HV, SCV

From table 4 it can be seen that in model one the R-value is 0.824 with an adjusted R-value of 0.678 while in model 2 the values are 0.858 and 0.735 respectively. These can be interpreted as, in model 1 , Home variables can account for $67.9 \%$ of the observed variance in parental involvement in school adjustment while the addition of school variables increased the percentage of variance that can be accounted for to $73.5 \%$. Consequently the second model is the most useful in explaining parental involvement in school adjustment of pupils.

\section{DISCUSSION OF FINDINGS}

The findings on table revealed the level of parental involvement in school adjustment. Findings showed respondents views concerning the parental involvement in school adjustment, It can be deduced from the findings that most of the respondents indicated that high level of parental involvement is necessary in school adjustment while some of the respondents were of the opinion that moderate level of parental involvement will be needed for school adjustment, in fact, some respondents suggested that very high level is necessary. This finding agreed with the view of McFadyen-Ketchum, Bates, Dodge \& Pettit, (1996). They asserted that hostile, non-affectionate and coercive parenting indicated by yelling, insults, swearing, meanness and physical punishment has been found to be related to higher levels of behaviour problems, such as aggression and all these have impact on pupils' school adjustment. This is in agreement with the view of Pettit, Bates \& Dodge (1997). They posited that contrary, hostile and authoritarian parenting characterised by a high value being placed at obedience, little verbal give and take, few explanations of rules, a punitive orientation, and low warmth has been found to be related to poorer cognition and more behaviour problems in pupils school adjustment. Furthermore, Linver, Brooks-Gunn \& Kohen (2002) view is in consonance 
with the views of McFadyen-Ketchum, Bates, Dodge \& Pettit, (1996); and Pettit, Bates \& Dodge (1997. Linver, Brooks-Gunn \& Kohen, (2002) buttresses the views of McFadyen-Ketchum, Bates, Dodge \& Pettit, (1996); and Pettit, Bates \& Dodge (1997). They fluently posited that parental involvement is necessary in school adjustment. To them, parental involvement has been found to have strong impact on child outcomes and besides sympathetic authoritative parental involvement portrayed by firm control calm discussion, proactive teaching and warmth has also been found to be influential in pupils' school adjustment.

Results in Table 2 showed the effect of parental socio-economic status of parental involvement in pupils' school adjustment. Findings on Table 2 revealed level of parental involvement with the following levels: Very Low Level, Low Level, Moderate Level and High Level of Parental Involvement respectively. This is in line with the view of Adewunmi (2015) who purported that children of low class people attend low standard Public Primary School with inadequate infrastructure, inadequate teaching or instructional materials, incompetent and unqualified teachers and lack of school. Similar studies, Farrell (2003); Peter, Seeds, Goldstein and Coleman (2008); Deal and Peterson (2009); Baeck (2010) and Jafarov (2015) agrees with the view of Adewunmi (2015). They eloquently stress that the socio-economic status of parents have influence on pupils' adjustment

Moreover, findings in Table 3 revealed the relationship among home variables, school variables and parental involvement in school adjustment. That is, findings showed the correlation of the first two variables with parental involvement in school adjustment in order to determine which of them goes into the steps first. Findings in Table 3 indicated the two variables are significantly correlated to parental involvement in school adjustment. Furthermore, findings presented that the home variables seem to be more highly correlated with parental involvement in school adjustment. Therefore, consequently, findings in Table 4 portrayed that home variable goes into the steps first and school variables follows. This finding agreed with the views of Bronlènhrenner (1979). Bronlènhrenner reinforced that school readiness focused on children's readiness. He further buttress that there has been a recent expansion of these ideas to include the schools, families' and communities readiness for this pupils' transition and this recognises the interaction between children's inherent traits and the environmental and cultural context. Moreover, according to Bronlènhrenner (1979) ecological systems theory, child development occurs in the context of these overlapping interconnected influences and relationships. In the same vein, Dearing, McCartney and Taylor (2001) buttressed the opinions of Bronlènhrenner (1979). Dearing, McCartney and Taylor articulately claim that various child personalities play a role in school readiness. One such factor is children's early cognitive ability, which has consistently been found to influence cognitive and language abilities when starting school. They further reinforce that early cognitive ability has been found to be a relatively strong predictor of school readiness, having a large impact than other child characteristics such as gender, birth weight and family qualities such education, family structure, ethnicity, income amongst. Therefore, Bronlènhrenner (1979); and Dearing, McCartney and Taylor (2001) indicated that correlation exist among home variables, school variables and parental involvement in school adjustment of pupils. Additionally, Bronlènhrenner (1979); Dearing, McCartney and Taylor (2001) views are in line with the opinion of Duncan (2007) who maintained significant relationship exists among home variables, school variables and parental involvement in school adjustment of a child. Duncan further stress that the aforementioned variables and parental involvement in pupils are also predictive of later outcomes such as behavioural and emotional problems.

\section{CONCLUSiON}

From the results of this study, it was evident that rich environment facilitate an exquisite learning in children adjustment and that learning environment is crucial in the cognitive development of a child and school adjustment and that child-friendly environment promote children adjustment in school. It was also discovered that parents have a lot to do in creating a conducive home environment and that children taught under the same learning situation perform differently due to variation in the home factors. It was also further concluded that the relationship between the home and the need for closer relationship between parents, teachers and school, quality of the parent-pupil relationship as a predictor that determines early school adjustment of preschoolers. 


\section{RECOMMENDATIONS}

The need for closer relations between the home and the school cannot be overemphasized since the school is tending to share more and more in family functions.

The child is so to speak sandwiched between the parents at home and the teachers in the school and all are involved in a complex of relationship. The teacher must always remember that the child brings his parents to school with him, in the sense that their teaching is always present in his mind and conscience. There is therefore, likely to be conflict between the teaching of the home and the school and the effects of this can be the root of a child's problem, and a cause of his difficulties. The teacher cannot avoid his position as a parent figure or substitute (in-loco-parents). One important thing which teachers should also know is that they should be sensitized of their close relationship with pupils for it immensely assists learners to gain confidence and well adjusted.

It is also recommended that parents should be made aware of the need to make their children more confident, more self assertive and competent in their adjustment process and strong link must be created between schools and parents or the community members and issues regarding how well pupils adjust should be thrived at.

\section{REFERENCES}

[1] Adewunmi, O. (2015). Effect of Emotional Intelligence, Self-efficacy and Parental Involvement on Students' Academic Performance: A study on Secondary School Students in Abeokuta, Ogun State, Nigeria. European Academic research. pp 190.

[2] Baeck, U. K. (2010) 'Parental involvement practices in formalized home-school cooperation', Scandinavian Journal of Educational Research, 54(6), pp549-563.

[3] Bronfenbrenner, U, (1979) The Ecology Of Human Development, Cambridge, Mass., Harvard University Press.

[4] Carlson, V. (1991). Life-Span Human Development. Available: https://books.google.com.ng/books?isbn= 0534195822

[5] Deal, T. E. and Peterson, K. D. (2009, 2nd Edition) Shaping School Culture. San Fransisco: Jossey-Bass

[6] Dearing E, McCartney K, \& Taylor B. A. (2001). Change in family income-to-needs matters more for children with less. A Publication of US National Library of Medicine National Institutes of Health Available: https://www.ncbi.nlm.nih.gov/pubmed/11768145

[7] Duncan B. R. (2007). Young Children's Close Relationships: Beyond Attachment. Newburry Park: Sage Publication Inc.

[8] Egeland, B., Pianta, R., \& O’Brien, M. A. (1993). Maternal intrusiveness in infancy and child maladaptation in early school years. Development and Psychology, 5(3): $359-370$.

[9] Farrell, C. (2003). Low income families and household spending, DWP Research Report Series No. 192

[10] Guerin, D. W. \& Gottfried, A. W. (1994). Temperament and School Functioning during Early Adolescence. The Journal of Early Adolescence. 14(2): 104 - 113.

[11] Hill, K. L. (2001). Frameworks for Sport Psychologists: Enhancing Sport Performance. Available: https://books. google.com.ng/books?isbn=0736000143.

[12] Jafarov, J. (2015). Factors Affecting Parental Involvement in Education: The Analysis of Literature. Khazar Journal of Humanities and Social Sciences 18(4), Queen's University of Belfast.

[13] Linver, M. R., Brooks-Gunn, J., \& Kohen, D. (2002). Family processes as pathways from income to young children's development. Developmental Psychology. 38, $719-734$.

[14] McFadyen-Ketchum, S., Bates, J. E., Dodge, K. A. \& Petit, C. (1996). Temperament and Parent-Child Relations as Interacting Factors in Children's Behavioural Adjustment. Psychological Press Amazon.com

[15] Peters, M., Seeds, K., Goldstein, A. \& Coleman, N. (2008) Parental Involvement in Children's Education 2007. Research Report. DCSF RR034

[16] Petit, G., Bates, J., \& Dodge, K. (1997). Supportive parenting, ecological context, children's adjustment: A seven-year longitudinal study. Child Development, 68, $908-218$.

[17] Sanson, A., Ilemphill, A. E. \& Smart, D. (2002). Patterns and precursors of adolescent antisocial behaviour: The first report. Available: https://www.google.com.ng/search?ei=DoSlWvOeI6XJgAaU OYyYBQ\&q 
[18] Schweinhart, L. J. (2003). Benefits, Costs, and Explanation of the High/Scope Perry Preschool Program, Paper presented at the Meeting of the Society for Research in Child Development, April 2003.

[19] Steinitz, M. S., \& Werby, E. (1997). Parenting in Public: Family Shelter and Public Assistance. Available: https://books.google.com.ng/books?isbn=0231528671

\section{AUTHORS' BIOGRAPHY}

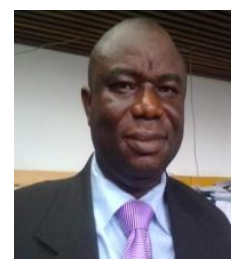

Dr B.A Adeyemi is an Associate Professor and currently the Director Institute of Education, Faculty of Education Obafemi Awolowo University Ile-Ife Osun State Nigeria.

Dr. (Mrs) V. O Adediran is a Lecturer 1 in the Obafemi Awolowo University Ile-Ife Osun State Nigeria.

Mr O.S Adewole is a Lecturer in the School of Education, Osun State College of Education Ila Orangun.

Citation: Dr. B. A. Adeyemi, Dr. (Mrs) V. O. Adediran, O. S. Adewole. "Influence of Parental Involvement, Parental Support and Family Education on Pupils' Adjustment in Lower Primary Schools in Osun State". International Journal of Humanities Social Sciences and Education (IJHSSE), vol 5, no. 4, 2018, pp. 67-75 doi: http://dx.doi.org/10.20431/2349-0381.0504007.

Copyright: () 2018 Authors. This is an open-access article distributed under the terms of the Creative Commons Attribution License, which permits unrestricted use, distribution, and reproduction in any medium, provided the original author and source are credited. 